\title{
Effects of Homocysteine and Hyperglycemia on the Proliferation of Aortic Vascular Smooth Muscle Cells of Obese Type 2 Diabetes Rat
}

\author{
Hyung Joon $\mathrm{Yoo}^{1, *}$, Sung Hoon $\mathrm{Yu}^{1,2, *}$, Young Jung $\mathrm{Cho}^{3}$, Hong Woo Nam ${ }^{3}$, Dong Hyun Kang ${ }^{1}$ \\ ${ }^{1}$ Division of Endocrinology and Metabolism, Hallym University Kangnam Sacred Heart Hospital, Hallym University College of Medicine, \\ Seoul, ${ }^{2}$ Division of Endocrinology and Metabolism, Hanyang University College of Medicine, Seoul, ${ }^{3}$ Department of Internal Medicine, \\ National Medical Center, Seoul, Korea
}

Corresponding Author: Hyung Joon Yoo, $\mathrm{MD}, \mathrm{PhD}$ Department of Internal Medicine, Hallym University Kangnam Sacred Heart Hospital, 1 Singil-ro, Yeongdeungpo-gu, Seoul 07441, Korea

Tel: +82-2-2639-5691 Fax: +82-2-2677-9756

E-mail: hjoonyoo@gmail.com

*These authors contributed equally to this study and should be considered co-first authors.

Received: May 8, 2017 Revised: June 14, 2017 Accepted: June 14, 2017
Background: The aim of this study was to investigate the role of homocysteine on the proliferation of rat aortic vascular smooth muscle cells (VSMCs) by measuring mitogen-activated protein (MAP) kinase under hyperglycemic conditions. Methods: Rat aortic VSMCs were isolated from Otsuka Long-Evans Tokushima Fatty and Long-Evans Tokushima Otsuka rats. VSMCs were incubated in the presence of homocysteine $(1 \mathrm{mM})$ with/without PD98059 $(30 \mu \mathrm{M})$ and wortmannin $(300 \mathrm{nM})$ for 48 hours in different concentrations of glucose $(5.5,25 \mathrm{mM})$. Proliferation was evaluated by methylthiazoletetrazolium (MTT), fluorescence-activated cell sorting (FACS), and western blot analyses. Results: In MTT and FACS analyses, the proliferation of VSMCs was increased by homocysteine. After PD98059 (30 $\mu \mathrm{M})$ and wortmannin (300 nM) treatment with homocysteine $(1 \mathrm{mM})$, the increased proliferation of VSMC caused by homocysteine, decreased to control levels. In Western blot analysis, immunoexpression of phospho-p44/42 MAP kinase was significantly increased by homocysteine $(1 \mathrm{mM})$. After PD98059 and wortmannin treatment, the increased immunoexpression of phospho-p44/42 MAP kinase was suppressed. Conclusion: These results suggest that the MAP kinase and PI3 kinase pathways are the main mechanisms involved in rat VSMC proliferation caused by homocysteine under hyperglycemic conditions.

Key Words: Homocysteine, Hyperglycemia, Vascular smooth muscle cell, Mitogen-activated protein kinase, Phosphoinositide 3-kinase

\section{INTRODUCTION}

Homocysteine is a sulfur-containing amino acid formed during methionine metabolism. In 1969, McCully first described the association between hyperhomocysteinemia and vascular disease in a patient with homocystinuria, an inborn error of homocysteine metabolism ${ }^{1)}$. Recent epidemiological studies have reported a clear association between hyperhomocysteinemia and cardiovascular mortality and atherothrombotic events. Hyperhomocysteinemia is regarded as an independent risk factor of vascular disease and insulin resistance. Insulin resistance has been implicated in the development of atherosclerosis and frequently coexists with common proatherogenic disorders such as neointimal hyperplasia ${ }^{2)}$. Recent studies demonstrated that hyperhomocysteinemia increased neointima formation and elastin and collagen deposition $^{3)}$. Although the pathophysiology linking hyperhomocysteinemia to vascular disease remains unclear, numerous stu- dies have suggested that homocysteine is related to impaired vascular endothelial and smooth muscle cell function ${ }^{4-6)}$.

The proliferation of vascular smooth muscle cells (VSMCs) is the most prominent hallmark of early atherosclerosis, which is also observed when premature atherosclerosis is present with diabetes ${ }^{7,8)}$. Okada et al. ${ }^{9)}$ showed a significant relationship between hyperhomocysteinemia and an increased risk of coronary arteriosclerosis in patients with type 2 diabetes. Cardiovascular disease is the leading cause of mortality in patients with diabetes. Patients with severe hyperhomocysteinemia typically have neurological abnormalities or premature arteriosclerosis and develop cerebral thrombosis or myocardial infarction at approximately the age of 30 years ${ }^{10)}$. A strong correlation between plasma homocysteine concentrations and mortality has been reported in patients with angiographically confirmed coronary heart disease. A metaanalysis showed that an increase of $5 \mathrm{mM}$ in plasma homocysteine enhanced the risk of cardiovascular disease by 1.6 to 1.8 fold $^{11)}$. It is now recognized that hyperhomocysteinemia 
is a common risk factor for cardiovascular disease, similarly to smoking and hyperlipidemia ${ }^{2,12)}$.

Hyperhomocysteinemia promotes atherosclerosis primarily by injuring endothelial cells via hypomethylation and by altering hepatic lipid metabolism, thus increasing the uptake of modified-low-density lipoprotein by macrophages, leading to the accumulation of cholesterol and triglycerides in the vessel wall. The results of lipid analyses and low-density lipoprotein uptake assays suggested that hyperhomocysteinemia increases plasma total cholesterol and decreases high-density lipoprotein-cholesterol ${ }^{13)}$. The results of many experimental studies have suggested that reactive oxygen species, nuclear factor $\kappa B(N F k B)$ activation ${ }^{3)}$, and mitogenactivated protein (MAP) kinase ${ }^{14,15)}$ are important in VSMC proliferation caused by homocysteine. However, the exact mechanisms by which homocysteine causes proliferation of VSMCs under hyperglycemic conditions remain unclear.

In this study, we investigated the role of homocysteine in the proliferation of aortic VSMCs to investigate the signaling pathway with different concentrations of glucose in an obese type 2 diabetes rat model.

\section{MATERIALS AND METHODS}

\section{Study Animal}

Age-matched male Otsuka Long-Evans Tokushima Fatty (OLETF) rats, a model of spontaneous noninsulin dependent diabetes mellitus, and male Long-Evans Tokushima Otsuka (LETO) rats, a nondiabetic control model of OLETF rats, were kindly provided by Otsuka Pharmaceutical Co. (Tokushima, Japan).

\section{Cell Culture}

VSMCs were harvested from the thoracic aorta of 12-weekold male OLETF and LETO rats by elastase and collagenase digestion as previously described ${ }^{16,17)}$. The cells were grown in Dulbecco's modified Eagle's medium (DMEM, Gibco-BRL, Grand Island, NY, USA) containing 10\% fetal bovine serum $(\mathrm{FBS})$ in a $37^{\circ} \mathrm{C}, 5 \% \mathrm{CO}_{2}$ humidified incubator. At confluence, the cells were trypsinized using $0.125 \%$ trypsin in $0.005 \%$ ethylenediaminetetraacetic acid (EDTA). Cells from passages 7-13 were used for the experiments. The cells grew in a "hill and valley" pattern, which is characteristic of VSMCs in culture ${ }^{18)}$ and showed positive immunostaining with antismooth muscle $\alpha$-actin antibodies.

\section{Treatment of Cells With Reagents}

Cultured VSMCs were seeded into 96 -well plates $\left(1 \times 10^{4}\right.$ cells/well) in 10\% FBS DMEM and incubated for 48 hours. Quiescence was induced in the cells by incubation in $0.1 \%$ FBS DMEM for 24 hours before homocysteine addition. Different concentrations of homocysteine (Sigma, St Louis, MO, USA) were added (control, 0.01, 0.1, and $1 \mathrm{mM}$ ). Wells containing $1 \mathrm{mM}$ homocysteine were mixed or not mixed with PD98059, a MAP kinase inhibitor ( $30 \mu \mathrm{M}$, Sigma) and wortmannin, a phosphatidylinositol-3 kinase (PI3 kinase) inhibitor (300 nM, Sigma). The cells were then incubated for an additional 48 hours in 10\% FBS DMEM in the presence of different concentrations of glucose (5.5 and $25 \mathrm{mM})$.

\section{Cell Proliferation Test}

Cell proliferation was evaluated by the methylthiazoletetrazolium (MTT, Sigma) assay and expressed as cell viability $(\%)$. VSMCs were incubated in the presence of homocysteine $(1 \mathrm{mM})$ with/without PD98059 $(30 \mu \mathrm{M})$ or wortmannin (300 $\mathrm{nM})$ for 48 hours with different concentrations of glucose (5.5 and $25 \mathrm{mM}$ ). MTT solution $(5 \mathrm{mg} / \mathrm{mL}$ in phosphate-buffered saline) was then added to each well and the plates were incubated for 4 hours. The MTT formazan product was solubilized by the addition of dimethyl sulfoxide (Sigma), and absorbance was measured at $570 \mathrm{~nm}$ using an ELX800 (Biotek, Winooski, VT, USA).

\section{Flow Cytometric Analysis of DNA Content}

VSMCs were seeded in duplicate in 6-well plates. After 24 hours in DMEM containing $0.1 \%$ FBS, the medium was changed to $5 \%$ FBS. VSMCs from OLETF rats were harvested from the wells using phenol red-free trypsin-EDTA at 24 and 48 hours. The cells were immediately permeabilized and stained in the unfixed state using a solution of $0.5 \% \mathrm{wt} / \mathrm{vol}$ saponin and $0.1 \% \mathrm{wt} / \mathrm{vol}$ bovine serum albumin in phosphatebuffered saline containing $50-\mu \mathrm{g} / \mathrm{mL}$ propidium iodide and $50-\mu \mathrm{g} / \mathrm{mL}$ ribonuclease A. Data from the stained cell suspensions were acquired using a FACS Calibur flow cytometer (BD Biosciences, Franklin Lakes, NJ, USA) using Cell Quest software (BD Biosciences). The resultant DNA profiles were analyzed by considering the FL2 peak area and width and using the Modfit software (Verity Software House Inc., Topsham, ME, USA) to determine the percentage of cells in each phase of the cell cycle.

\section{Western Blot Analysis}

The cells cultured with homocysteine $(1 \mathrm{mM})$ with/without PD98059 $(30 \mu \mathrm{M})$ and wortmannin $(300 \mathrm{nM})$ for 48 hours were washed and lysed with lysis buffer (10 mM Tris, [pH 7.4], $1 \mathrm{mM}$ EDTA, 1\% sodium pyrophosphate [NP]-40, $0.1 \mathrm{mM}$ phenylmethylsulfonyl fluoride [PMSF], $20 \mathrm{nM}$ sodium vanadate, 
and $1 \times$ cocktail solution). The supernatants were analyzed using the Bradford assay (Bio-Rad, Hercules, CA, USA). Sodium dodecyl sulfate polyacrylamide gel electrophoresis was performed with a $10 \%$ resolving gel, followed by nitrocellulose membrane transfer (Bio-Rad). The membranes were blocked for 1 hour at room temperature $\left(23^{\circ} \mathrm{C}\right)$ in blocking solution (5\% skim milk in Tris buffer with Tween-20 [TBST, $200 \mathrm{nM}$ Tris, $500 \mathrm{mM} \mathrm{NaCl}, \mathrm{pH} 7.5,0.05 \%$ Tween-20]), and then incubated overnight at $4{ }^{\circ} \mathrm{C}$ with anti-phospho-p44/42 MAP kinase antibody (Cell Signaling Technology, Danvers, MA, USA), anti-phosphoinositide 3-kinase (PI3K) antibody (Cell Signaling Technology), and anti-NFKB antibody (Sigma). The membranes were washed with TBST (5 minutes, 3 times) and incubated with peroxidase-conjugated anti-mouse IgG antibody (Amersham Life Science, Amersham, UK). The membrane was washed and incubated using a Visualizer Western blot detection kit (Upstate, Lake Placid, NY, USA), and autoradiography was performed. Band intensity was analyzed by densitometry using Image $\mathrm{G}$ program.

\section{Statistics}

Data are expressed as the means \pm standard devaiton. Statistical analysis was performed with Student t-test or one-way analysis of variance. Values of $p<0.05$ were considered statistically significant.

\section{RESULTS}

\section{Effects of Homocysteine on the Proliferation of VSMCs}

The proliferation of VSMCs was significantly increased by homocysteine in a dose-dependent manner in all 12-week-old rats (OLETF and LETO) in the presence of normal glucose (Fig. 1). The proliferation of VSMCs was increased by homocysteine $(1 \mathrm{mM})$ in OLETF and LETO rats and at different concentrations of glucose (5.5 and $25 \mathrm{mM}$ ). In FACS analysis, the proliferation of VSMCs was increased after treatment with homocysteine $(1 \mathrm{mM})$. Flow cytometric analysis of DNA content revealed that a significantly greater percentage of homocysteine-treated VSMCs were in the G2M phase compared to controls at 24 and $48 \mathrm{~h}$ (Fig. 2). After PD98059 (30 $\mu \mathrm{M})$ and wortmannin $(300 \mathrm{nM})$ treatment with homocysteine $(1 \mathrm{mM})$, the increased proliferation of VSMCs caused by homocysteine, decreased to control levels in all rats and at different concentrations of glucose (OLETF rats in high glucose: homocysteine vs. homocysteine+PD98059, 180.0\% $\pm 2.1 \%$ vs. $120.1 \% \pm 2.0 \%$; homocysteine vs. homocysteine+ wortmannin, $180.0 \% \pm 2.1 \%$ vs. $122.5 \% \pm 6.4 \%$; p $<0.05$ ) (Fig. 3). Following treatment with PD98059, proliferation showed a greater decrease in VSMCs compared to controls in the MTT assay. We determined the cell numbers before and after drug treatment to investigate the cytotoxicity of PD98059. There were no changes in cell numbers between the control group and treatment group (PD98059) (Supplementary Fig. 1). Following treatment with homocysteine in 49-week-old OLETF rats (overt hyperglycemic), the proliferation of VSMCs also increased at both concentrations of glucose tested (5.5 and $25 \mathrm{mM}$ ).

VSMC proliferation in the presence of a high glucose concentration $(25 \mathrm{mM})$ was significantly higher than that in the presence of normal glucose concentration $(5.5 \mathrm{mM})$ in OLETF rats $(116.2 \% \pm 4.3 \%$ vs. $100.0 \% \pm 8.2 \%, p<0.05)$ and LETO rats $(120.5 \% \pm 10.3 \%$ vs. $100.0 \% \pm 4.2 \%, p<0.05)$. Increased VSMC
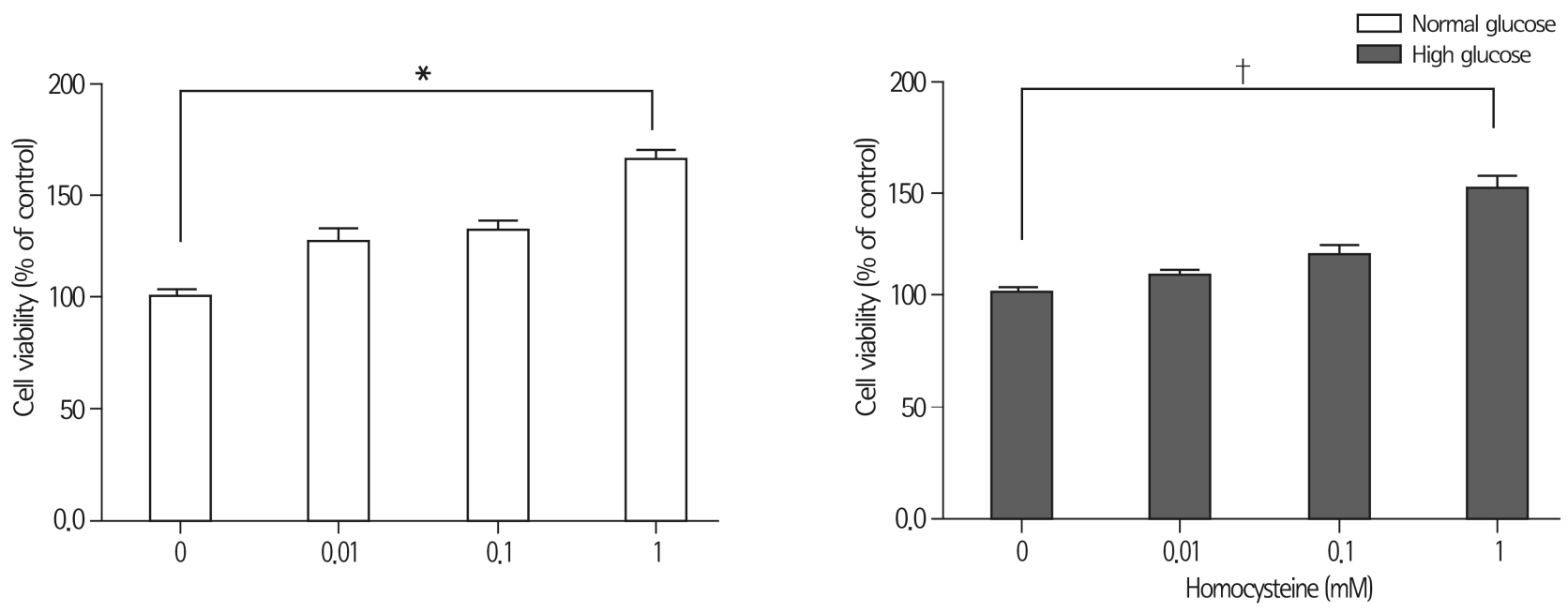

Fig. 1. Effect of homocysteine on the proliferation of vascular smooth muscle cells of Otsuka Long-Evans Tokushima Fatty rats at various concentrations. Data are expressed as the mean \pm standard deviation. Normal glucose, $5.5 \mathrm{mM}$; high glucose, $25 \mathrm{mM}(\mathrm{n}=5) .{ }^{*} \mathrm{p}<0.05$ vs. no homocysteine treatment. ${ }^{\dagger} \mathrm{p}<0.001$ vs. no homocysteine treatment. 
proliferation with homocysteine was significantly higher in the presence of high glucose than in the presence of normal glucose concentrations in OLETF rats $(178.1 \% \pm 7.3 \%$ vs. $155.0 \% \pm 11.5 \%, \mathrm{p}<0.05)$ and LETO rats $(164.5 \% \pm 7.3 \%$ vs.
$132.2 \% \pm 8.7 \%, p<0.05)$. VSMC proliferation was significantly higher in the OLETF rats compared to in LETO rats with normal glucose concentration (Fig. 3).

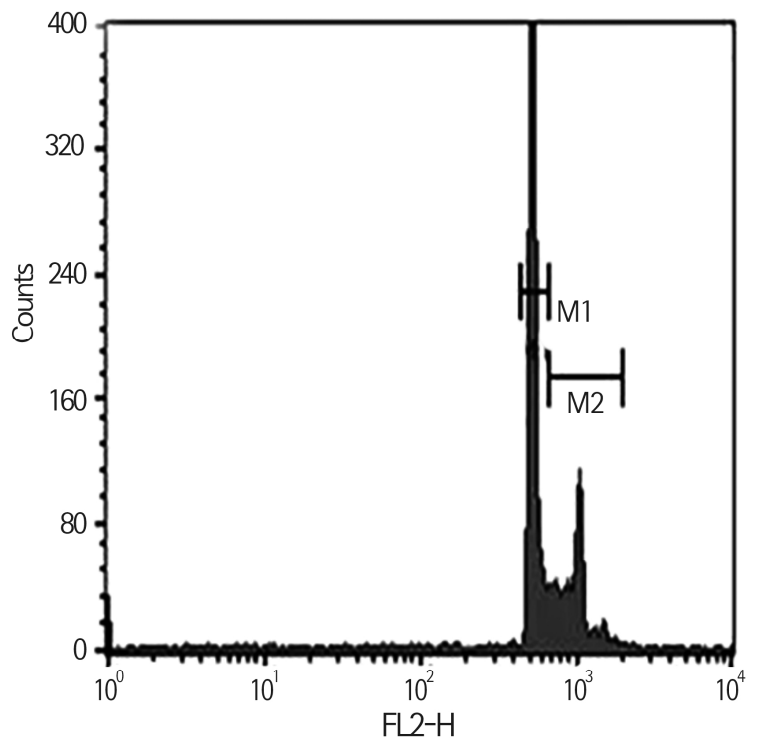

(A)

\begin{tabular}{ccc} 
Marker & $\%$ Gated & $\%$ Total \\
\hline All & 100.00 & 100.00 \\
M1 & 67.44 & 67.44 \\
M2 & 26.49 & 26.49
\end{tabular}

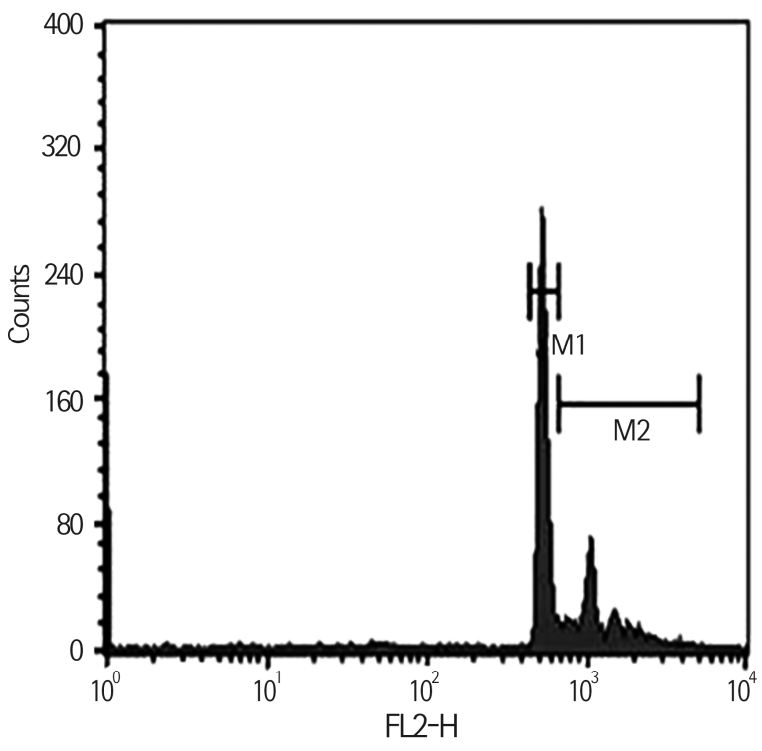

(B)

\begin{tabular}{ccc} 
Marker & $\%$ Gated & $\%$ Total \\
\hline All & 100.00 & 100.00 \\
M1 & 56.44 & 56.44 \\
M2 & 33.73 & 33.73
\end{tabular}

Fig. 2. Fluorescence-activated cell sorting analysis of homocysteine-treated vascular smooth muscle cells. (A) No homocysteine treatment. (B) homocysteine $(1 \mathrm{mM})$ treatment.

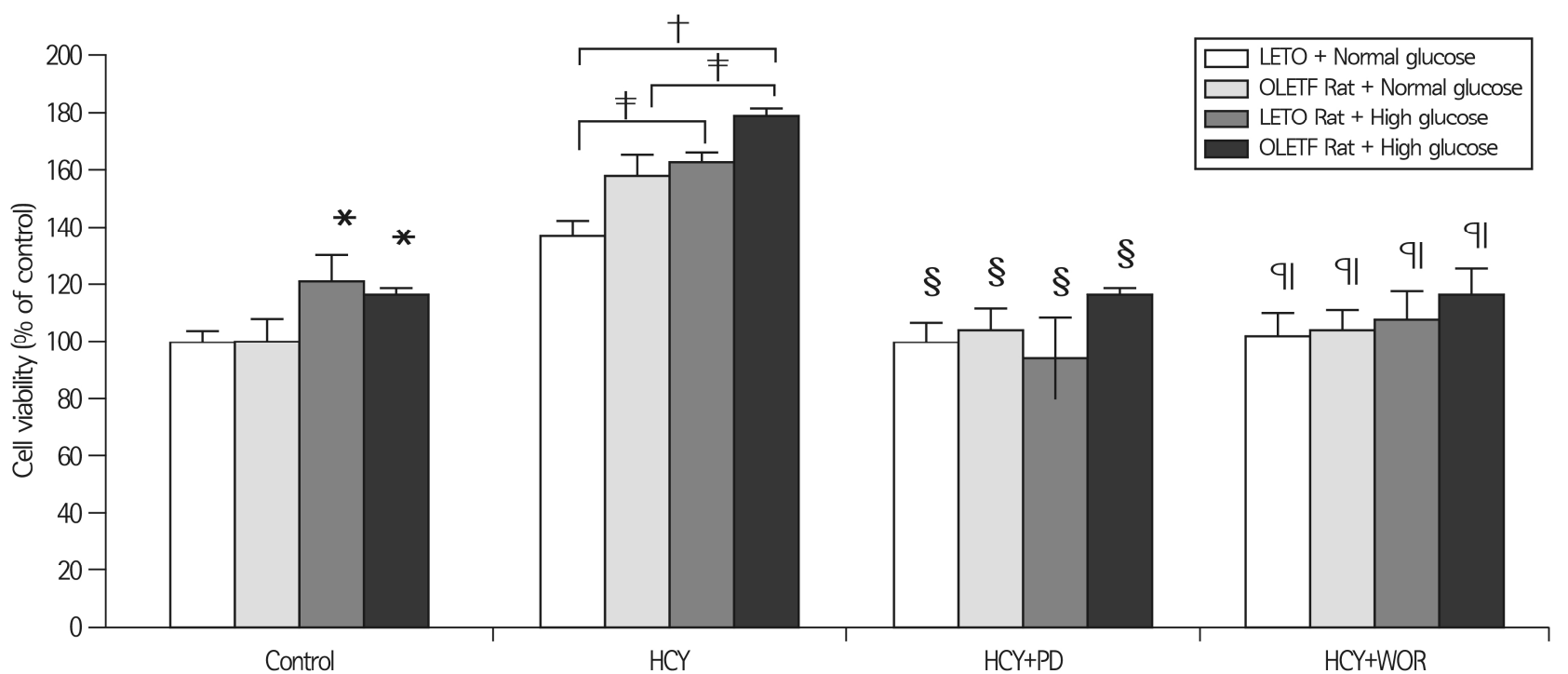

Fig. 3. Effect of homocysteine on the proliferation of vascular smooth muscle cells at different concentrations of glucose. Data are expressed as the mean \pm standard devaiton. OLETF, Otsuka Long-Evans Tokushima Fatty; LETO, Long-Evans Tokushima Otsuka; HCY, homocysteine $(1 \mathrm{mM})$; PD, PD98059 $(30 \mu \mathrm{M})$; WOR, wortmannin $(300 \mathrm{nM})$; normal glucose, $5.5 \mathrm{mM}$; high glucose, $25 \mathrm{mM}(\mathrm{n}=5) .{ }^{*} \mathrm{p}<0.05$ vs. normal glucose. ${ }^{\dagger} \mathrm{p}<0.05$ vs. control. ${ }^{\mp} \mathrm{p}<0.05$ vs. normal glucose with homocysteine. ${ }^{\$} \mathrm{p}<0.05$ vs. homocysteine. "p $<0.05$ vs. homocysteine. 


\section{Role of MAP Kinase and PI3 Kinase Pathways on the Proliferation of VSMCs: Western Blot Analysis}

Immunoexpression of phospho-p44/42 MAP kinase was significantly increased by homocysteine $(0.1,1 \mathrm{mM})$ in a dosedependent manner among all rats at both normal and highglucose concentrations (Fig. 4). Immunoexpression of nonphospho-p44/42 MAP kinase was not changed by homocysteine treatment $(1 \mathrm{mM})$ in all rats. However, immunoexpression of phospho-p44/42 MAP kinase was significantly increased by homocysteine $(1 \mathrm{mM})$ in all rats at both concentrations of glucose. After PD98059 and wortmannin treatment, the increased immunoexpression of phospho-p44/42 MAP kinase was suppressed (Fig. 5). Immunoexpression of $\mathrm{NFKB}$ was not changed by homocysteine $(1 \mathrm{mM})$ in OLETF rats (Fig. 6).

\section{DISCUSSION}

VSMCs play an important role in the development and progression of atherosclerosis ${ }^{4,8)}$. Hyperglycemia enhances the proliferation of VSMCs, which is a critical step in the pathogenesis of atherosclerosis development ${ }^{19-21)}$

Homocysteine is the product of the combined pool of homocysteine, homocystine, mixed disulfides involving homocysteine, and homocysteine thiolactone found in the plasma of patients with hyperhomocysteinemia; approximately $5 \%-7 \%$ of the general population has mild hyperhomocysteine$\mathrm{mia}^{22)}$. Homocysteine is formed during methionine metabolism and is metabolized by one of 2 pathways: remethylation or transsulfuration. Hyperhomocysteinemia is caused either by a genetic abnormality of the enzymes involved in homocysteine metabolism (cystathione $\beta$-synthase deficiency) or by nutritional deficiencies in vitamin cofactors (folate, vitamin $\mathrm{B}_{12}$, and vitamin $\mathrm{B}_{6}$ ).

Although the exact pathophysiologic mechanism linking hyperhomocysteinemia to atherosclerosis remains unclear, numerous studies have suggested that homocysteine causes endothelial dysfunction, increases oxidative stress and lipid peroxidation, and stimulates the proliferation of $\mathrm{VSMCs}^{22)}$,

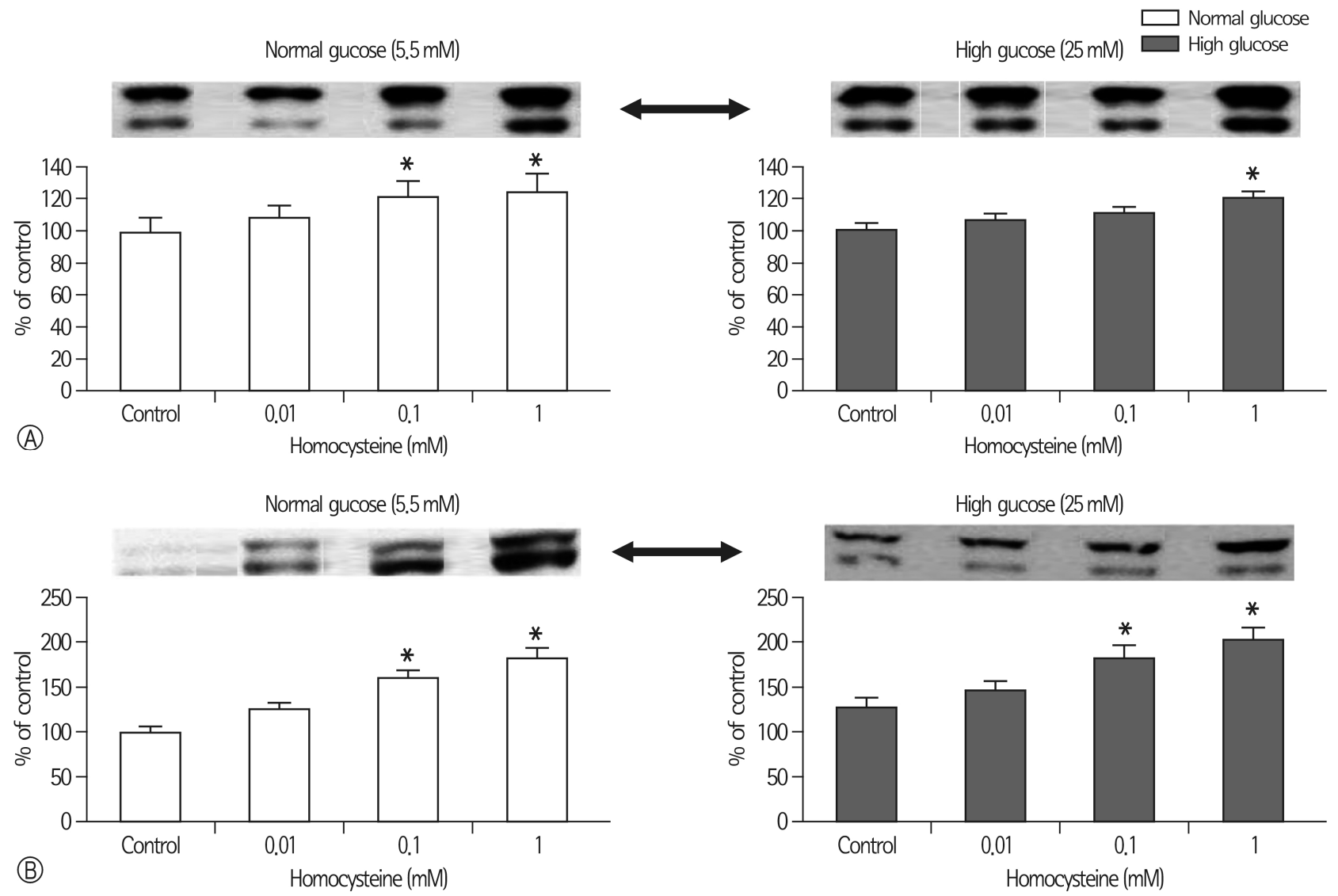

Fig. 4. (A) OLETE rat, (B) LETO rat. Enhanced effect of homocysteine on proliferation of vascular smooth muscle cells (VSMCs) through the mitogen-activated protein kinase (MAPK) signaling pathway determined by western blot analysis. Data are expressed as the mean \pm standard devaiton. OLETF, Otsuka Long-Evans Tokushima Fatty; LETO, Long-Evans Tokushima Otsuka; HCY, homocysteine; $\leftrightarrow$, phospho-p44/ 42 MAP kinase antibody $(42 / 44 \mathrm{kDa})(\mathrm{n}=3)$. ${ }^{*} \mathrm{p}<0.05$ vs. control. 


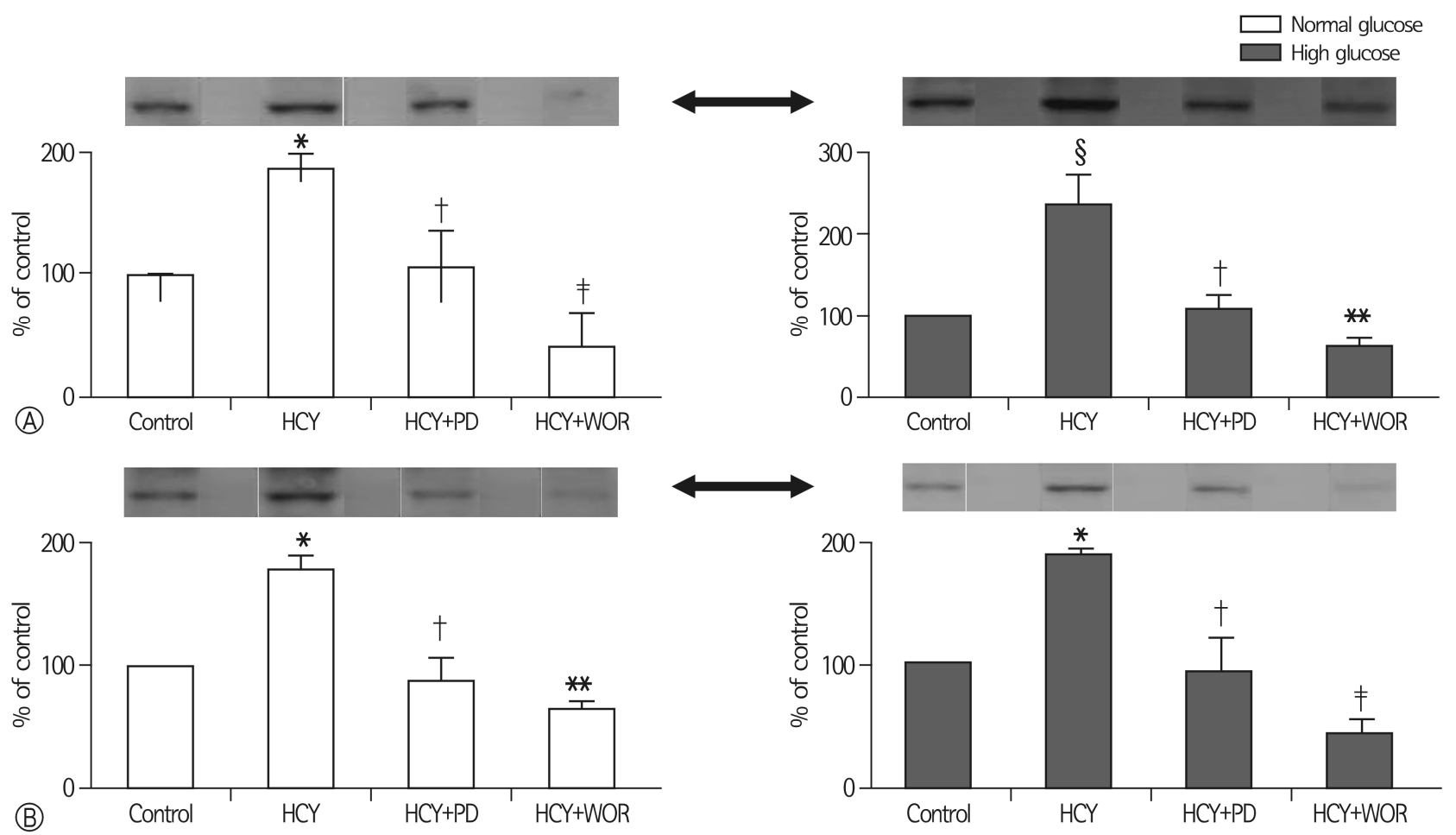

Fig. 5. (A) OLETE rat, (B) LETO rat. Role of the mitogen-activated protein (MAP) kinase pathway in the proliferation of vascular smooth muscle cells: Western blot analysis. Data are expressed as the mean \pm standard devaiton. OLETF, Otsuka Long-Evans Tokushima Fatty; LETO, Long-Evans Tokushima Otsuka; HCY, homocysteine (1 mM); PD, PD98059 (30 $\mu \mathrm{M})$; ↔, phospho-p44/ 42 MAP kinase antibody $(42 / 44 \mathrm{kDa})(\mathrm{n}=3) .{ }^{*} \mathrm{p}<0.05$ vs. control. ${ }^{* *} \mathrm{p}<0.05$ vs. homocysteine. ${ }^{\dagger} \mathrm{p}<0.05$ vs. control. ${ }^{\dagger} \mathrm{p}<0.05$ vs. HCY+WO.

NFKB activity, and monocyte chemoattractant protein-1 expression ${ }^{4)}$.

In the past several years, many studies have reported the relationship between homocysteine and VSMC proliferation. Brown et al. ${ }^{23)}$ detected extracellular signal-regulated protein kinase 2 activation by homocysteine, and Tsai et al. ${ }^{24)}$ reported that homocysteine stimulates the expression of mRNA of cyclin $A$ and $D$, which was shown to be related to the control of cell growth. Doronzo et al. ${ }^{25)}$ reported that homocysteine increases matrix metalloproteinase-2 activity in cultured human VSMCs.

The OLETF rats used in this study are an animal model for the spontaneous development of obese type 2 diabetes. Hyperglycemia and chronic complications develop during aging; by 24 weeks, OLETF rats exhibit significant diabetes based on the oral glucose tolerance test ${ }^{26)}$. In this study, we used both 12- and 49-week-old rats, just prior to the development of diabetes and the overt diabetes model. LETO rats were from the same colony as the OLETF rats, but they did not develop diabetes and were used as nondiabetic controls.

The results of our study showed that phospho-p44/42 MAP kinase activation was increased by homocysteine in a dosedependent manner at normal $(5.5 \mathrm{mM})$ and high $(25 \mathrm{mM}) \mathrm{glu}-$

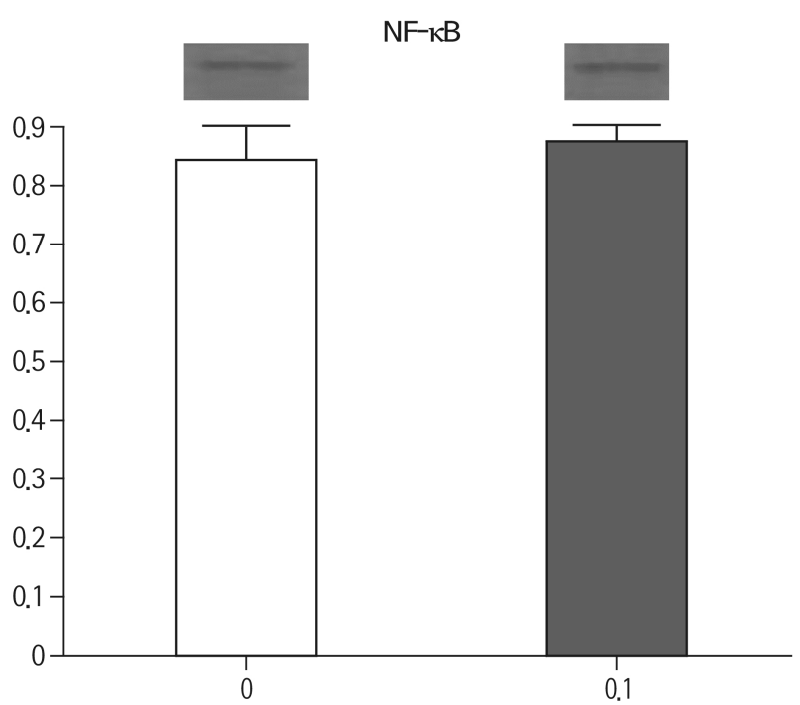

Fig. 6. Immunoexpression of nuclear factor $\kappa \mathrm{B}(\mathrm{NF} \kappa \mathrm{B})$ by treatment with homocysteine. HCY, homocysteine $(1 \mathrm{mM})$.

cose concentrations. The increased proliferation of VSMCs and expression of phospho-p44/42 MAP kinase by homocysteine (1 mM) were suppressed by PD98059, a MAP kinase inhibitor, and wortmannin, a PI3 kinase inhibitor. There was 
no difference in suppression between PD98059 and wortmannin according to the MTT assay results; however, MAP kinase activation was suppressed more significantly by PD98059 than by wortmannin, as shown by western blot analysis. Activation of phospho-p44/42 MAP kinase was partially blocked by inhibitors of PI3 kinase, and PI3 kinase was partially blocked by PD98059 (MAP kinase inhibitor). This may be because of crosstalk between the MAP kinase and PI3 kinase pathways.

Our results showed that the MAP kinase pathways play a role in the proliferation of VSMCs caused by homocysteine. In addition, the findings were similar in all rats, suggesting that genetic background does not significantly contribute to the results.

In conclusion, our results suggest that the MAP kinase and PI3 kinase pathways are the main mechanisms involved in the proliferation of VSMCs of genetically determined obese type 2 diabetes rats caused by homocysteine under hyperglycemic conditions.

Conflicts of Interest Disclosures: The researchers claim no conflicts of interest.

\section{Acknowledgements}

This study was funded by the Korean Geriatrics Society (2009).

\section{Supplementary Material}

Supplementary Fig. 1 can be found via http://www.e-agmr. org/src/sm/agmr-21-78-s001. pdf.

\section{REFERENCES}

1. Mujumdar VS, Tummalapalli CM, Aru GM, Tyagi SC. Mechanism of constrictive vascular remodeling by homocysteine: role of PPAR. Am J Physiol Cell Physiol 2002;282:C1009-15.

2. Jiang C, Zhang H, Zhang W, Kong W, Zhu Y, Zhang H, et al. Homocysteine promotes vascular smooth muscle cell migration by induction of the adipokine resistin. Am J Physiol Cell Physiol 2009;297:C1466-76.

3. Tan H, Shi C, Jiang X, Lavelle M, Yu C, Yang X, et al. Hyperhomocysteinemia promotes vascular remodeling in vein graph in mice. Front Biosci (Landmark Ed) 2014;19:958-66.

4. Wang G, Siow YL, O K. Homocysteine stimulates nuclear factor kappaB activity and monocyte chemoattractant protein- 1 expression in vascular smooth-muscle cells: a possible role for protein kinase C. Biochem J 2000;352 Pt 3:817-26.

5. Refsum H, Ueland PM, Nygård O, Vollset SE. Homocysteine and cardiovascular disease. Annu Rev Med 1998;49:31-62.

6. Bao XM, Zheng H. Atorvastatin attenuates homocysteine-induced migration of smooth muscle cells through mevalonate pathway involving reactive oxygen species and p38 MAPK. Clin Exp Pharmacol Physiol 2015;42:865-73.
7. Ross R. Atherosclerosis: an inflammatory disease. N Engl J Med 1999;340:115-26.

8. Schwartz SM, Campbell GR, Campbell JH. Replication of smooth muscle cells in vascular disease. Circ Res 1986;58:427-44.

9. Okada E, Oida K, Tada H, Asazuma K, Eguchi K, Tohda G, et al. Hyperhomocysteinemia is a risk factor for coronary arteriosclerosis in Japanese patients with type 2 diabetes. Diabetes Care 1999;22:484-90.

10. Homocysteine Studies Collaboration. Homocysteine and risk of ischemic heart disease and stroke: a meta-analysis. JAMA 2002; 288:2015-22.

11. Boushey CJ, Beresford SA, Omenn GS, Motulsky AG. A quantitative assessment of plasma homocysteine as a risk factor for vascular disease. Probable benefits of increasing folic acid intakes. JAMA 1995;274:1049-57.

12. Folsom AR, Nieto FJ, McGovern PG, Tsai MY, Malinow MR, Eckfeldt JH, et al. Prospective study of coronary heart disease incidence in relation to fasting total homocysteine, related genetic polymorphisms, and B vitamins: the Atherosclerosis Risk in Communities (ARIC) study. Circulation 1998;98:204-10.

13. Wang $H$, Tan $H$, Yang F. Mechanisms in homocysteine induced vascular disease. Drug Discov Today: Dis Mech 2005;2:25-31.

14. Woo DK, Dudrick SJ, Sumpio BE. Homocysteine stimulates MAP kinase in bovine aortic smooth muscle cells. Surgery 2000; 128:59-66.

15. Kartal Ozer N, Taha S, Azzi A. Homocysteine induces DNA synthesis and proliferation of vascular smooth muscle cells by interfering with MAPK kinase pathway. Biofactors 2005;24: 193-9.

16. Yoo HJ, Kozaki K, Akishita M, Watanabe M, Eto M, Nagano $\mathrm{K}$, et al. Augmented $\mathrm{Ca} 2+$ influx is involved in the mechanism of enhanced proliferation of cultured vascular smooth muscle cells from spontaneously diabetic Goto-Kakizaki rats. Atherosclerosis 1997;131:167-75.

17. Yu SH, Yu JM, Yoo HJ, Lee SJ, Kang DH, Cho YJ, et al. Antiproliferative effects of rutin on OLETF rat vascular smooth muscle cells stimulated by glucose variability. Yonsei Med J 2016;57:373-81.

18. Bochaton-Piallat ML, Ropraz P, Gabbiani F, Gabbiani G. Phenotypic heterogeneity of rat arterial smooth muscle cell clones. Implications for the development of experimental intimal thickening. Arterioscler Thromb Vasc Biol 1996;16:815-20.

19. Alipui C, Ramos K, Tenner TE Jr. Alterations of rabbit aortic smooth muscle cell proliferation in diabetes mellitus. Cardiovasc Res 1993;27:1229-32.

20. Natarajan R, Gonzales N, Xu L, Nadler JL. Vascular smooth muscle cells exhibit increased growth in response to elevated glucose. Biochem Biophys Res Commun 1992;187:552-60.

21. Yoo HJ. Proliferation of cultured vascular smooth muscle cells (VSMCs) obtained from aortas of insulin dependent diabetic rats. J Korean Geriatr Soc 1997;1:48-54.

22. Welch GN, Loscalzo J. Homocysteine and atherothrombosis. N Engl J Med 1998;338:1042-50.

23. Brown JC, Rosenquist TH, Monaghan DT. ERK2 activation by homocysteine in vascular smooth muscle cells. Biochem Biophys Res Commun 1998;251:669-76.

24. Tsai JC, Wang H, Perrella MA, Yoshizumi M, Sibinga NE, Tan LC, et al. Induction of cyclin A gene expression by homocysteine 
in vascular smooth muscle cells. J Clin Invest 1996;97:146-53.

25. Doronzo G, Russo I, Mattiello L, Trovati M, Anfossi G. Homocysteine rapidly increases matrix metalloproteinase- 2 expression and activity in cultured human vascular smooth muscle cells. Role of phosphatidyl inositol 3-kinase and mitogen activated protein kinase pathways. Thromb Haemost 2005;94:1285-93.

26. Kawano K, Hirashima T, Mori S, Saitoh Y, Kurosumi M, Natori

T. Spontaneous long-term hyperglycemic rat with diabetic complications. Otsuka Long-Evans Tokushima Fatty (OLETF) strain. Diabetes 1992;41:1422-8. 